\title{
EXISTENTIAL MOTIFS IN SLOVAK LITERATURE WITH THE ISSUE OF THE SHOAH
}

\author{
${ }^{a}$ MONIKA ADAMICKÁ \\ Fakulta stredoeurópskych štúdií, Univerzita Konštantína \\ Filozofa v Nitre, \\ Dražovská 4, 94974 Nitra \\ email: amonika.adamicka@ukf.sk
}

This work was supported by research project UGA "Jews and post-war destinies of Slovak Jewry in the work of Anton Baláž” based on the contract n. X/1/2020.

Abstract: The study deals with existential motifs in selected fiction and memoir works of Slovak literature, which thematically focus on World War II. and the Holocaust of the Slovak Jewish minority. As we considered the fact that many works of Slovak provenance with this issue were published (especially after 1989), we focused only on a selection of those works, which contains fiction and non-fiction literature and a selection of those works, which contains fiction and non-fiction literature and memoir works written by surviving Jews, in which they gave valuable testimony about the Holocaust and anti-Semitism of the war-torn Slovak state and post-war society. Based on the interpretation and analysis of Shoah-themed works, we detect recurring survival, Auschwitz traumas, and the motif of The Lost Generation.

Keywords: anti-Semitism, Auschwitz traumas, existentialism, Holocaust, memoir literature, The Lost generation.

\section{Introduction}

The topic of the Holocaust appeared in Slovak literature in the first post-war years. The occurrence of Judaism in works of Slovak provenance published after 1945 is generally divided into three periods (Vargová, 2011, p. 59). The first period is in the range of 1945 - 1948, when mainly documentary works were published (e. g. Jozef Lánik, Peter Karvaš). 50s - 60s indicates the second period during which were published works by Rudolf Jašík, Ladislav Mňačko, Leopold Lahola and others. The third period is limited to the 1980s and 1990s and is characterized as a reflection and reassessment of the past. During these years, some works by Hela Volanská or Ján Johanides were published.

In the first post-war years, only a few memoir and fiction works were published in Slovak literature, the main theme of which was the solution of the Jewish question during the Slovak state. "Even in the post-war period, when this minority was already decimated to a minimum, the topic of Judaism did not become ideologically appropriate" (Šuša, 2015b, p. 40). The reason was, among other things, the connection of Judaism with capitalism, which was contrary to the position of the nascent socialist establishment, which advocated the gradual nationalization and abolition of private property. Nevertheless, some fiction works about the Shoah were published - perhaps the most famous novel on this subject, St. Elizabeth's Square (1962, Námestie svätej Alžbety) written by the author of non-Jewish origin, Rudolf Jašík. This framework also includes the novel The Death Is Called Engelchen (1959, Smrt' sa volá Engelchen) by Ladislav Mňačko, which is not directly related to the final solution of the Jewish question, but its Jewish character Marta is a symbol of the suffering of the Jewish minority in the post-war period in connection with the existential solution of the traumas that Jews had experienced, although she was not interned in the death camp. And, of course, the work of Ladislav Grosman The Shop on Main Street (1965, Obchod na Korze), which was adapted to the Oscar-winning film of the same name, cannot be overlooked. At the same time, a few works by Jewish authors were published, especially in the period up to the 1950s and during the period of political detachment in the 1960s, for example the books of Jozef Lánik What Dante Did Not See (1965, Čo Dante nevidel), Manca Schwalbová The Extinguished Eyes (1948, Vyhasnuté oči), Hela Volanská Meeting in the Woods (1948, Stretnutie v lesoch) and also short stories of Leopold Lahola published in the book The Last Thing (1968, Posledná vec). In the case of authors of Jewish origin, it is mostly memoir literature (Lánik, Schwalbová, Volanská), several of them can be termed camp or concentration literature - in the case of memoirs from concentration camps (Lánik, Schwalbová).
The year 1989 and the change of political establishment made it possible to write openly about the Jewish question and the Holocaust. Literature reflecting the issue of Judaism in Slovakia during World War II. and in the post-war years has certain specifics. In particular, memoir works (compared to the period before 1989) by authors of Jewish origin from a non-literary environment began to be published, the aim of which is not the aesthetic experience of the recipient, but the mediation of facts about the Holocaust and concentration camps. At the same time, memoir works were translated into Slovak, which were published in foreign publishers after the emigration of their authors abroad, e.g. the work of Rudolf Vrba, which was originally published in 1963 in Great Britain and was not translated into Slovak until 2015.

\section{Materials and Methods}

The study is an analysis and interpretation of works of Slovak literature on the topic of racial persecution of Jews during World War II. with a chronological overlap to the post-war period. Based on the fact that a large number of books about the Shoah have been published in Slovak literature (we have managed to identify 73 works), we rely only on selected works, on the basis of which it is possible to demonstrate the researched motifs. In addition to analysis and interpretation, we also use the method of comparison. Since most of the works written by Slovak authors have not been translated into English, translation of the citations was made by the author of the study.

The works that are the subject of comparison must be divided into four groups:

1. Memoir works of Jewish authors: Manca Schwalbová - The Extinguished Eyes (1948, Vyhasnuté oči), Hela Volanská As at the Foreign Wedding (2009, Ako na cudzej svadbe), Rudolf Vrba - Alan Bestic - I Cannot Forgive (1963, Nemôžem zabudnút'. Utiekol som z Osvienčimu), Jozef Lánik - What Dante Did Not See (1965, Čo Dante nevidel), Iboja Wandall-Holm - The Mulberry (1991, Moruša)

2. Fiction works of Jewish authors: Leopold Lahola The Last Thing (1968, Posledná vec), Andrea Coddington - The Jewess (2010, Židovka), Peter Karvaš - The Night in My City (1979, Noc v mojom meste); short story The Old Man and Fate (1979, Starý pán a osud), Milan Richter - The Wrecked Temple in Me (2002, Vo mne zbúraný chrám), Ladislav Grosman - The Shop on Main Street (1965, Obchod na Korze)

3. Fiction works of non-Jewish authors: Rudolf Jašík - St. Elizabeth's Square (1962, Námestie svätej Alžbety), Ladislav Mňačko - The Death Is Called Engelchen (1959, Smrt' sa volá Engelchen), Anton Baláž - The Rift (2014, Trhlina), Klára Jarunková - The Black Solstice (1979, Čierny slnovrat)

4. Fiction and non-fiction works of non-Jewish authors based on the personal testimonies of the surviving Jews: Anton Baláž - non-fiction The Transports of Hope (2010, Transporty nádeje); novel The Land of Forgetting (2000, Krajina zabudnutia): from the personal testimonies of Pavla and Eugénia Schreiber; short story Simon the Pilgrim (2014, Šimon Pútnik): from the life story of Martin Rodan, Ivana Havranová - The Abducted (2017, Odvlečení): written as a dialogue with surviving Jews

Since the main subject of the work is the analysis of existential motifs, in the introductory chapter we will also deal with the basic postulates of the philosophy of existentialism. We will focus mainly on the work of Martin Heidegger Being and Time (1927, Sein und Zeit). We deliberately choose his work in connection with the Jewish question as a contrast to the existential experiences of Jews, because Heidegger was a supporter of the German idea of National Socialism and was involved in the service of Nazism. Despite his political beliefs, he had an affair with his Jewish student, Hannah Arendt, who is 
the author of the book Eichmann in Jerusalem/ A Report on the Banality of Evil (1963). However, from the point of view of existential motifs in literature, the works of French philosophers and fiction writers Jean Paul Sartre and Albert Camus are also very important. We will develop the philosophy of Karl Jaspers, a representative of the German line of existentialism, in connection with the question of guilt (of Jews for their own survival).

\section{Existencialism}

In most works about the Shoah, it is possible to recognize certain peculiarities. It is mainly about capturing a personal traumatic experience, beating inability to change the situation, loss or, conversely, the strengthening of faith, "often the intertwining of personal and socio-historical aspects and the attempt to describe this phenomenon from several, often scientific, aspects as a machinery of power and evil" (Šuša, 2015a, p. 130). All these specifics can be described as existential motifs, which are characteristic for the entire Slovak literature of the post-war period. This is especially true for memoir literature with the main theme of the final solution to the Jewish question.

The existential line of Slovak literature in the 1940s was associated mainly with the French philosopher of existentialism, Jean Paul Sartre, while "it was primarily an emphasis on motives such as freedom, will, possibility, anxiety, fate, the tragic feeling of life, while the existentialist conception of these motives accentuated the overlap to the ethical, social and political level" (Domorák, 2017, p. 193). Existentialism or the philosophy of existence deals with the human being in its broadest sense of meaning, while existence has no direction at first (after the birth). It could be said that they were inclined to the Plato's fall to birth ${ }^{1}$. The term throwing into the world (as a parallel to the Plato's fall into birth) is one of the basic ontological concepts of the philosophy of Martin Heidegger, who developed the issue of human existence in his main work Being and Time. Heidegger calls human existence in the world as a stay (Dasein) in a specific time and space, and these two quantities are not determined by one himself (he derives the concept of throwing into the world from this). From this springs the existential dissatisfaction of people amplified by the finiteness of being at the moment of death. And it is the awareness of death that brings dynamism into existence, because if we remove the infiniteness of being, the being itself will also disappear (Heidegger, 2002, p. 272)

Existentialists generally emphasize the importance of death. At the same time, individuals are most aware of their own existence in borderline life situations, when experiencing fear, danger, near death. The above explicitly implies the frequent occurrence of existential motifs in fiction and memoir literature about the Shoah - the main and episodic characters of the stories balanced between life and death, either during internment in labor camps, where they saw death up close or were directly threatened by death, as well as in efforts to resist the fate of the Jewish minority in Central Europe by fleeing concentration camps.

For Jean Paul Sartre, who belongs to the atheistic line ${ }^{2}$ of existentialism, death is the final point of human existence. Human life has no specific goal or direction. Life is therefore absurd, as is death, because there is not posthumous redemption. In connection with this statement, Sartre's philosophy might seem in opposition to the rich spiritual life of the Jews believing in God and adhering to His commandments. During World War II., however, it was his philosophy that largely reflected the inner

\footnotetext{
In his teaching about the soul, Plato argued that at the birth of man the human soul involuntarily moves from the perfect world of ideas (true being) to the imperfect world of things (false being) - he calls it the term fall into birth. The soul does not remember the world of ideas, during life it tries to remember it through learning - Plato calls it anamnesis. In this we see a certain parallel with the philosophy of existentialism, with an involuntary being which is not intended at birth, it is formed during a person's life. ${ }^{2}$ Existentialism is divided into two directions: atheistic and theistic From the theistic Existentialism is divided into two directions: atheistic and theistic From the theistic direction the Slovak as well as Czech literature were influenced by French philosopher Gabriel Honore Marcel. See also: Gallik, Ján - Vargová, Zuzana: Durychova novela „Boží duha“ vo filmovom spracovaní. In: World Literature Studies, vol. 2, nr. 3, 2019,
pp. 28 - 41.
}

disposition of a believing Jew who, under the influence of inhuman conditions in the camps, loses his faith, does not believe in God, or in the meaning of one's own existence. The absurdity of life is also the basis of Albert Camus' philosophy. In his works he captures the tragedy of human existence, brings a reflection on the meaning of one's life, concluding that the basic feeling and state of man is the absurdity in the relationship between him and the world resulting from the knowledge that the world itself has no goal and thus sense.

\section{Existential motifs in the literature about Shoah}

Based on a comparison of selected works of Slovak literature of the post-war (1945 - 1989) and post-revolutionary period (after 1989), it is possible to detect basic, recurring existential motifs:

- feelings of humiliation, degradation of human dignity and loss of identity - man as a number without a name, man as an animal or otherness of Jewish blood,

- feelings of guilt for one's own survival manifested in the first post-war years exacerbated by the disappointment of the inhabitants of towns and villages from the return of the surviving Jews,

- feelings of anxiety and fear, recurring nightmares and phobias - can be termed Auschwitz trauma haunting survivors,

- $\quad$ the motif of The Lost Generation of young people who had to deal with feelings of early adulthood and the problem of reintegration into life in the post-war period.

\subsection{The Loss of Identity}

The motif of the degradation of human dignity is connected with the internment of Jews in labor camps in Slovakia or in German concentration camps. It is related to the inhuman conditions in which the Jews found themselves - lack of food, poor hygiene, but also feelings of constant humiliation by the guardsmen, often in connection with the forced nudity to which they were exposed upon arrival at the camp or during selections. In the camp, the man lost his name, his personal belongings, which testified to his identity, the prisoners became only numbers without a name. Iboja Wandall-Holm mentions this aspect of the loss of human nature in her book: "They threw all the objects that testified to our identity into a large basket. They lay there at their mercy, betrayed. We lost the last rest of our identity with clothes"(Wandall-Holmová, 1998, p. 227). Manca Schwalbová also calls the prisoners numbers: "Hundreds die every day by being shot or in the gas, from typhus or malnutrition. But hundreds of new slaves, new numbers come every day"(Schwalbová, 2011, p. 32). And she further writes: "John and William were executed. I was left alone in the midst of numbers" (ibid., p. 71). Rudolf Vrba captured it in a similar way - unification, erasing of external differences between people associated with the loss of name and identity leads to the creation of a herd of anonymous prisoners in the camp: "Now I belong to the herd, striped clothing, tattooed number, anonymous, unknown, and if I am fast enough and mow goodness, as they say, I will remain inconspicuous" (Vrba Bestic, 2015, p. 120). Schwalbová combines the loss of human dignity with the ability to kill others for their own rescue: "We are standing. We haven't felt hunger for a long time, just hatred, crazy hatred. We would be able to kill dozens of friends. So that we can finally sit down" (Schwalbová, 2011, p. 112).

Hunger, the desire for food and its lack changed man's behavior into an animal. In his memoir, Rudolf Vrba writes about it: "That's when I saw life in a concentration camp, which degrades a human being. Like jackals, they threw themselves on leftovers, fought and growled. At that time, I saw another aspect of life in the camp, something completely foreign to my nature, something disgusting after all" (Vrba - Bestic, 2015, p. 92).

It was in the degradation of their dignity to the level of an animal that the Jews saw a way of self-salvation, of thinking only of one's own survival, of not looking at others. In an interview with Ivana Havranová, Marta Szilárd says: "It was all so very 
humiliating ... But let me tell you something. When a person is humiliated completely to the beastly level, he thinks only of how to survive" (Havranová, 2017, p. 30). In a memoir book written in novel form, Jozef Lánik goes even further - he degrades man to the level of an animal and elevates the animal to a man. In the eyes of the Nazis, the prisoners became dogs, animals (dogs) were promoted to humans. This is evidenced by the instruction of the SS man, who issued to the dogs: "Man, bite the dog!" (Lánik, 1989, p. 55). The existential paradigm of degrading human dignity develops in the work also in another aspect. People do not become an animal only in the eyes of fascist commanders. By limiting people in the camp to satisfying their basic biological needs, the only thing that "controls their mind is the natural instinct of self-preservation" (Vargová, 2011, p. 73).

The motif of degraded human identity also found its way into the fictional work of authors of Jewish and non-Jewish origin. The Jewish author Leopold Lahola combines the loss of human dignity with the personal death of an individual - in the short story Bird's Song (Vtáčí spev) - the story does not take place in a concentration camp, but the main theme is the humiliation of a Jew in front of others: "Tears flowed against his will. How one should live now was in his mind. After all, how it is possible to get down from the branches, stand on both feet and live on as if he had never been on that tree. [...] - You killed me in cold blood, - Vogel repeated more quietly, even if he didn't care so much whether the one standing down there heard it or not" (Lahola, 1968, p. 65).

Rudolf Jašík also writes about the loss of identity with the loss of his name - before coming to the camp and tattooing the number of the prisoner instead of the name, the Jews were still people with their own identity, although they were outcasts: "The outcasts lie, sit and remain silent. They still have names, surnames, and they still flee to their memories, there, behind the rough walls of the Jewish school, into the streets and alleys of the city under the vineyard hill"(Jašík, 1976, p. 257). Then he named the Jews before being transported to the German concentration camps only by the term "name". He wanted to emphasize that they had not yet lost human identity associated with the transformation of a man into a number without a name after arriving at the camp: "Names stand, names wait. Their names still remain" (ibid., p. 273). In Rudolf Jašík's work, we also encounter in the introductory chapters the motif of the differentness of Jewish blood in comparison with non-Jews. He used the metaphor of drinking Jewish blood to herald the future mass murder of Jews: "He could feel the blood pulsing in her veins, quite ordinary, red, and yet different, extremely differentJewish. He did not know that the city would soon be flooded with herds, which would drink it in litres, hectolitres until suffocation" (ibid., 31). Hela Volanská also depicts Jews as others, different from the majority, in her memoir. Like Igor from Jašík's novel, she does not distinguish between Jews and non-Jews, because man "will be man, simply - man, no Jews, non-Jews" (Volanská, 2009, p. 68). The otherness of the Jews, their culture, religion, way of life and, last but not least, their physical appearance was the cause of creating negative stereotypes associated with the idea of Jewish control of society. And it was these attitudes towards the Jewish minority that led to the hateful, xenophobic manifestations that culminated during the Holocaust. Looking back on how far hatred towards minorities can lead, in central Europe "there spreads further the myth of the domination of the Jews, on which anti-Semites [...] have been working hard for centuries" (Gallik, 2018, p. 84).

\subsection{Guilt for One's own Survival}

The events of World War II. and the final solution (not only) to the Jewish question raise questions of guilt, or rather responsibility for the deaths of millions of Jews or other racially and politically inappropriate people. Karl Jaspers, a representative of the German line of philosophy of existentialism, addresses this issue in his book The Question of German Guilt, where he distinguishes four types of guilt (Jaspers, 2006, pp. 25 - 26):
1. criminal guilt: consists in a deliberate violation of the law, the crime is an objectively provable act violating the legislation,

2. political guilt: unlike criminal guilt, it is based on the guilt of statesmen, with the consequences of their actions being borne by nationals,

3. moral guilt: it is the fault of the individual for his actions, while the person is also responsible for his political or military decisions,

4. metaphysical guilt: it is based on solidarity between people, everyone is co-responsible for injustice in the world, especially for the crimes that take place in his presence.

The political but also the moral guilt of the political representatives of the states, who agreed with the deportations of Jews, the citizens of that state, can be explicitly deduced from this division. In defining moral guilt, the attempt to defend their actions by claiming, that there was a war and they acted under dictation from fascist Germany, is groundless. Because it is never true that an order is an order (Jaspers, 2006, p. 25 - 26).

In opposition to the guilt of the Nazis is the guilt experienced by the surviving Jews after returning from the concentration camps, which is a recurring motif in Shoah-themed memoir literature and fiction. A specific case is the short story The Rift from the book Portraits of Survival by Anton Baláž. In his work, in addition to the guilt of Jews who survived, he also addresses the issue of guilt of non-Jews in relation to Jews who became victims of the Holocaust. Their guilt stems from their indifference to Jewish fate, from the fact that they did nothing to save them. It persecutes them in the form of a nightmare, delusions, which in the story are a metaphor for their impure conscience. These negative phenomena from the past, which accompany them to the present, are symbolized by a rift in the land through which individual events from the time of the war and the deportation of Jews to concentration camps come to the surface: "But the rift is advancing, the past is rolling on them from all sides ..." (Baláž, 2014, p. 239). The remorse here is linked to justice, a certain satisfaction against the Jews, who also became victims of mass murder for the indifference of the nonJews and with their tacit consent, because "the past is just waiting, patiently, for years and decades, for the smallest rift to open somewhere to attack us in the name of justice" (ibid.). From this fact follows (based on Jaspers' division of guilt) the metaphysical guilt of non-Jews, their co-responsibility for the actions that took place in their presence.

In connection with the guilt of non-Jews against the fate of the Jews, the question of white Jews arises. They were people of non-Jewish descent who hid Jews during the persecution or helped them escape. Evidence of the help of the non-Jewish Slovak population to the Jews is the number of awarded Slovaks with the title of Righteous Among the Nations, which is awarded by the organization at the Yad Vashem Memorial. By the end of 2019, 597 people from Slovakia were on the list. ${ }^{3}$ White Jews are directly mentioned by Ladislav Grosman in his book The Shop on Main Street. This term is associated with the character of Tóno Brtko, who was a simple, kind-hearted man, but was forced by his own wife and brother-in-law to forcibly seize the haberdashery of the old Jewish woman Lautman. And it is his brother-in-law Kolkocký who calls him a white Jew: "You are acting like a white Jew. A white Jew is worse than an ordinary Jew because he is not a Jew and helps a Jew" (Grosman, 1992, p. 59). The position of a good man and at the same time a fear for his own life caused him an existential disunity in deciding whether to give a Jewish woman to the Nazis for his rescue or try to save her.

In Baláž's work with a Jewish theme, feelings of the Jews' guilt for their own survival also appear. Apart from the short story The Rift (in the character of Aranka, who was the only survivor of the Shoah from their large family), this motif became the basis for the portrayal of the character Miriam from the novel

\footnotetext{
${ }^{3}$ https://www.pribehyspravodlivych.sk/spravodlivi-medzi-narodmi/
} 
The Land of Forgetting. Miriam, like Aranka, was the only one who returned home after the war, to an apartment that no longer belonged to her, because it was occupied by their former maid. Miriam tries to make up for her survival by working for the Palestinian Authority, which was a co-organizer of a large Jewish aliyah to Israel. However, the most tragic character in the novel is the Jew Kalina, who, among all the characters, experiences the most of his own existence. Unlike Miriam, who lost her relatives under the influence of political circumstances, Kalina himself sent his family to death in a concentration camp, when he added the number of Jews to the transport with his family members on the eve of Jewish largest feast day Yom Kippur. After the war, he experienced literally existential torments associated with feelings of guilt for his life and the death of his loved ones. He is haunted by memories of his wife Rosa, who asked him for forgiveness before his deportation (Yom Kippur is a holiday of reconciliation, when Jews ask for forgiveness for those they have hurt), although she has not blamed him: "she asked me for forgiveness ... Me, who voluntarily sent them to death, she asked me for forgiveness" (Baláž, 2014, p. 188). The whole story of Kalina captured in the novel is his preparation for the transition to eternity. He ended his life under the weight of conscience by suicide.

The motif of guilt for one's own survival is also in the prologue to Ivana Havranová's book The Abducted, in which Pavel Traubner writes: "For many following years, I woke up sweaty of a nightmare and terrible remorse about why I survived, and thousands of my children's peers, who were guilty only of being Jews, ended up in gas chambers and flew out soot through the chimneys of crematoria. What's more, sometimes this remorse catches me even after seventy-five years since I was born" (Havranová, 2017, p. 6). In an interview with Alexander Bachnár, Havranová uses a quote from Ellie Wiesel, who claimed that the Holocaust did not have six, but seven million victims. "The seventh million are the survivors" (ibid., p. 9). And for the rest of their lives, they will bear the existential burden of their own survival.

In the same way, Leopold Lahola in the short story Conversation in the First Person (Rozhovor v prvej osobe) connects the survival of Jews with a dead existence, their life is not a full-fledged being. He inserted these motifs into the character of a young doctor who, despite surviving the Shoah, tried to die. He considered his being to be corrupt: "...I myself am what is wrong. I'm spoiled. The death took some of us, the others were spoiled by death [...] We don't live, we just stayed alive. And that is the difference" (Lahola, 1968, p. 180). According to the author, the survival of the Jews, who moved in the camps on the border of life and death, is a sin against nature, their being is a kind of life after death. Nature has not adapted man to survive in extreme conditions of long-term starvation and physically demanding work. Based on this claim, Jews had to die while being interned in concentration camps and exposed to these superhuman conditions. Some of them nevertheless survived, but did not know what to do with their lives, which, according to the rules of nature, should no longer belong to them: "... and I do not know, kill me, I do not know what to do now, when I did not perish" (ibid., p. 181).

A similar motif of coping with the past became the main theme of Lahola's short story The Funeral of David Krakower (Pohreb Davida Krakowera). The character of Keldich appears here as Krakower's conscience. He came to remind him the incident from the execution of the Jews in the camp, when the singer Krakower sang a funeral song with the disapproval of the surrounding Jews waiting to be executed: "Who gave the singer the right to make it a legitimate funeral, they asked with crushed glances" (ibid., p. 172). And he saved his life by this act, but not the lives of others. From Keldich's point of view, Krakower changed the act of murder to the act of a funeral rite, thus mitigating the guilt of the executioners: "What happened there was multiple murder. It should have stayed a murder forever. However, you made the murder a rite" (ibid., p. 173).
Ladislav Mňačko also deals with the meaning of the survival of Jews (but also non-Jews) after the war in his novel The Death Is Called Engelchen. The character of the Jew Marta is one of the most tragic characters in Slovak literature. "War takes her everything, including respect for herself" (Adamická, 2019, p. 39). Although she did not experience cruel treatment of the Jewish minority during the war in connection with the final solution to the Jewish question, the way she managed to save herself (collaborating with the Germans) made her a human wreck and her survival and subsequent unnecessary existence is in contrast to millions of Jews whose death was pointless. Volod'a, who blames himself for burning the village Ploština, asks the existential question of the meaning of his and Marta's survival: "Did it have to be paid like this? It had to, of course, but then the war was to be consistent, not to keep alive wrecks like Martha ... like me ... Wouldn't it be better for her - not to live? " (Mňačko, 2016, p. 37). He sees his disability as a just punishment for guilt for burning the village: "It seemed fair to me that I would remain crippled. I will be at least partially clean with the past, no one will be able to say about me - behold, one from Ploština, one of those who caused it" (ibid., p. 30). Unlike Marta, Volod'a had a sense of satisfaction that helped him deal with his guilt in connection to the victims of the village. It was different in the case of Marta, who could live a full life after the war and be grateful for her own survival. However, she was not punished for the deeds she committed during the war to survive. She did not bear the weight of her existence and ended her life by suicide. The character of Marta is a kind of parallel to the person of Mata Hari (ibid., p. 41), a Dutch courtesan and a World War II. spy who was executed in France for spying for Germany. However, Mata Hari, unlike Marta, was punished for her espionage activities.

\subsection{Auschwitz Traumas}

The feelings of anxiety and fear that persecuted the surviving Jews in the postwar period can be generally described as Auschwitz traumas. They are very closely related to the horrors experienced in the concentration camps, and it could be said that they are a direct consequence of them. At the same time, they result directly from the loss of identity, from the humiliation and degradation of human dignity. In the post-war period, the memories returned to Jews in the form of a recurring nightmare, but also in the form of subliminal phobias. All this was compounded by the grief of the loss of loved ones who became victims of mass murder.

Constant fear, feelings of a certain form of insecurity were mentioned in interviews with Ivana Havranová by several surviving Jews. Juraj Kohlmann, who spent most of his childhood in the Bergen-Belsen camp, describes it in this way: "I have been afraid and anxious ever since. It comes every time I get into a more difficult situation. You just cannot get rid of it. All my life I have been accompanied by a form of uncertainty. And I have seen this in almost all of us" (Havranová, 2017, pp. 66 - 67). Otília Winterová mentions this in a similar way. She remembers from Auschwitz especially the great fear that haunts her to this day: "I don't remember anything! It's just that I was very scared! I was afraid. Still! And I think about that fear sometimes now. It returns" (ibid., p. 120). Gertrúda Zúbeková directly connects her anxiety with the fear that the situation could be repeated: "I still have that fear in me! Whether they will not expel the Jews again somewhere in Germany!" (Havranová, 2017, p. 81).

The Auschwitz traumas also got into the poetry of the Jewish author, Milan Richter, who was born in the post-war period, but his family was marked by the tragedy of the Holocaust. The Holocaust and the fates of Slovak Jews were included in his collection The Wrecked Temple in Me, which contains 33 poems in Slovak, 11 of which he also translated into English and 7 into German. He wrote the poems between 1972 and 2002, and except for those one which were published in the collections The Pollen (1972, Pel'), The Safe Place (1987, Bezpečné miesto), Roots in the Air (1992, Korene vo vzduchu), Behind Velvet Curtains (1997, Spoza zamatových opôn) and Angel with Black 
Feathers (2000, Anjel s čeirnym perím) the book contains even never published poems. The motifs of the Holocaust are depicted as recurring nightmares persecuting survivors, e.g. in the poem On the Interface (Na rozhraní) (Richter, 2002, p. 11).

In her novel The Jewess, Andrea Coddington very sensitively describes the lingering fear of the main character's mother as a result of her internment in a German death camp. Throughout the text, there is the narrator in the first person (self-narrator), whereby the story gets the character of memoirs, acquires authenticity and lets the reader believe that the story has become or it is really possible. Fear is associated with the fear of lack of food and thus the preservation of their lives, but also with feelings of loneliness and the loss of their own peace: "Only later did I understand why food was paramount and the fear of being hungry haunted her all her life. Only later did I understand the pain in her eyes. Not just so oppresive, dense and never fading. Mom could not be enjoyed. Be calm. The past bound her. She was hated as a young girl" (Coddington, 2010, p. 28). These feelings, which are the result of trauma, haunted her for the rest of her life, more intensely shortly after the end of the war. The author derives this from the iniquity experienced, the humiliation caused by Christians: "I know she was terrified. Mom never stopped being afraid. It was long after the war and she still had a panicked fear of policemen, army, soldiers, men in uniform. [...] She experienced injustice when others pointed on her just because they were Christians" (ibid.).

The Auschwitz traumas become one of the main themes of Anton Baláž's novel The Land of Forgetting. Although the plot of the novel takes place in the first post-war years, during the summer of 1949, the author in a retrospective returns to the camp experiences of two main characters, Miriam and Erna, and then captures how the horrors they experienced affected their post-war life. The Holocaust memories of Miriam and Erna are the memoirs of real Jews Pavla and Eugénia Schreiber, whose life story became an inspiration for him to write the work (Pavla Schreiberová is the mother of Martin Rodan, currently an associate professor at the Hebrew University in Jerusalem who emigrated to Israel in 1968). In the work, the author develops two Auschwitz traumas that fundamentally influenced the existence of the surviving Jews, namely a phobia of nudity and a phobia of dirt. At the same time, he looks for solutions to cope with trauma and start living a full life. These motifs run through the whole story of the novel, with a gradual rebirth of the main characters, coping with the past and overcoming the fear of one's own nudity and contact with unclean things.

The author developes the phobia of nudity in the character of Miriam. This morbid fear stems from the forced nudity to which she was subjected after her arrival in Auschwitz. It was a feeling of shame for the young girls, many of whom never undressed before strangers. And it was "that forced nudity that made her a spoiled woman" (Baláž, 2014, p. 32). A phobia of nudity prevents her from living the full life of a young woman, she is afraid of touch and intimate coexistence with a man. In an interview with Jakub, she admits: "I am not yet ready to answer a man's touch. I have experienced too many such touches ... glances at my body that I did not desire ... I am a humble and corrupt woman, Jakub" (ibid., p. 43). Miriam's forced nudity stands in stark contrast to the voluntary nudity of prostitutes, who she met regularly and constantly reminded her the depravity of her own body: "Their sensual laughter, cleavage, sales but unforced nudity irritated Miriam when she became her involuntary witness on her return to her apartment in the alley behind the back of the neological synagogue. It always reminded her the different, forced nudity of her own body, from which she still cannot break free" (ibid., p. 19). On the one hand, the nudity, existential and morbid fear of one's own body complicates her the social life, especially coexistence with the opposite sex, but on the other hand, she is aware of the need, even the necessity, to overcome these traumas. She feels owed to thousands of other bodies, other lives that ended up in cremation furnaces (Baláž, 2014, p. 35).
From the opposite point of view, Leopold Lahola captures the impact of forced nudity on Jewish survivors in the short story The Random Acquaintance (Náhodná známost') from the book The Last Thing. Nudity, or rather disgust from nudity, is depicted here from the point of view of a man who saw a number of exposed, humiliated female bodies during the selections, and this feeling of disgust persisted in him even in the post-war period. In a medical experiment in which he participated, it was bad for him to look at naked women: "I was sick [...] They disgusted me. One human body is beautiful, when there are many of them, they cease to be human" (Lahola, 1968, p. 218).

The phobia of dirt is the second Auschwitz trauma captured by Anton Baláž in the character of Erna in the novel The Land of Forgetting. Erna came to Auschwitz a little later than Miriam, so she was not concerned with forced, degrading nudity after arrival to the camp. For this reason, she did not suffer from phobia of nudity in the post-war period, but due to poor hygienic conditions in the camp, she could not bear contact with objects that were dirty from her point of view. It affected her daily life, restricted her in trivial things like sleeping under a blanket or traveling by public transport, because "when I see a dirty railroad carriage, dirty clothes, lousy military blankets, I get so disgusted that I can't control myself' (Baláž, 2014, p. 100). The phobia of dirt stemmed directly from the camp dirt, which she did not even realize during her internment, she did not perceive it, but the disgust got into her subconscious and affected her further life in the post-war period. However, she did no longer connect the dirt only with Auschwitz. She talks about the dirt of the East, which is related to culture, the way of life of Eastern countries (she came to this conclusion after visiting Tel Aviv): "There she understood that there was such a thing as the 'dirt of the East', that it was not just something related to Auschwitz, but it had to do with the country, with the culture, with the world getting so badly dirty" (ibid., p. 78). The dirt of the East can be understood here as a metaphor in two different meanings. The first meaning is the comparison of the dirt of the East to the Soviet Union (to the Eastern Block). Not only in this novel, but in several of his works, the author portrays the period of socialism between 1948 and 1989 negatively, sometimes even ridiculing it. For example, his novel The Camp of Fallen Women (1993, Tábor padlých žien) is a grotesque of socialism, in which he ridicules the efforts of the socialist regime to re-educate prostitutes from Bratislava in the Forced Labor Camp in Nováky. The event around the character of the photographer Jakub from the novel The Land of Forgetting, who was forced to photograph a state contract connected with the humiliation of a Jew-merchant, is also an allusion to the dirt of the Soviet Union: "He is looking at a thin stream of water. How clean it is, he thinks. He remembers Erna's amazement at how she let the water flow between her fingers. He remembers what she said about the filthy beautiful world. He admitted that it was true. And now he will add his work to this filth? Will he give the dirt another face, another defiled Jewish face?" (ibid., p. 205). The quote above also suggests the second meaning of the metaphor of the East dirt, and thus the persistent anti-Semitism in post-war Czechoslovakia or in the whole Eastern Block. One of the main themes of the novel is xenophobia, the persistent negative stereotyping of Jews as enemies of individuals feared for their property they had forcibly confiscated from the Jews during the war, but also as enemies of the new system of government. After photographing the humiliation of a Jewish businessman, Jakub feels dirty, and his feeling of dirt here is directly related to xenophobia towards Jews, and he regrets that he took part in something like this: "Jakub only rinses his hands in the water, he does not want to soil it with his face" (ibid., p. 205).

\subsection{Motif of The Lost Generation}

Literary direction, or rather the avant-garde group of The Lost Generation, which was formed around the American writer Gertrude Stein, appears in world literature after World War I. and its representatives are famous names such as Ernest Hemingway, John Doss Passos, John Steinback, James Joyce, Marcel Proust and others. The prose writers of The Lost Generation reflect the pessimistic feelings of the war-torn young 
generation which returned from the battlefields of World War I. and could not integrate into society, because their lives were interrupted at a sensitive young age. From this point of view, it is obvious that their works are full of the existential motifs of a person excluded from society under the influence of lived horrors, the motifs for seeking the meaning of life in the postwar period. The following feelings are very aptly summarized in the end of the novel All Quiet on the Western Front (1929, Im Westen nichts Neues) by Erich Maria Remarque: "We will no longer be able to come to life! They will not even understand us - because the older generation, which survived these years with us, already had its existence and vocation, and will now return to the old places where it will forget about the war. Behind us grows a younger generation, similar to us as we were. It will be foreign to us and will move us to the background. We are useless to ourselves; we will grow, some will adapt, others will succumb, and many will be clueless. The years will melt away and we will eventually perish" (Remarque, 1966, pp. 163-164).

Feelings of The Lost Generation are very affirmative with feelings of guilt for their own survival, the futility of the survival of corrupt people whose lives are distorted after the horrors of war - the motif, which was captured in the novel The Death Is Called Engelchen by Ladislav Mňačko. Unlike Marta and Volod'a from this novel, who have to deal with their unnecessary existence after the war, however, the fate of Paul Bräumer from the novel All Quiet on the Western Front ends happily for him, he dies in October 1918, "one day, when the front was so calm and quiet that the message from the battlefield was limited to the sentence: All Quiet on the Western Front..." (ibid., p. 164). Death was a redemption for him, freeing him from the suffering of The Lost Gneration. The author demonstrates this fact in Paul's posthumous facial expression: "He had such a calm expression on his face as if he were almost satisfied that it ended like this" (ibid.).

The motif of The Lost Generation also got into literature in the 1960s. Czech literature speaks about its second wave, which is thematically related to World War II. In the post-war period, people had to deal with similar feelings, regardless of whether they were involved in fighting in the military, in partisan groups, or as Jews and other racially and politically persecuted people who were interned in concentration camps and fought for their existence. The motif of difficult coping with the experienced traumas, psychological and existential problems in reintegrating into postwar life are an important part of the literature about the Holocaust, whether the memories captured in the memoir literature of Jewish authors or fiction and non-fiction literature of non-Jewish authors.

The attitudes of the lost generation depicted in literary works can be compared with the testimony of Yehuda Lahav, which was captured by Anton Baláž in the non-fiction The Transports of Hope. The life of a young student Yehuda was affected by World War II. and the racial persecution of the Jews. After the war, he returned to study, but returning was not easy. He was marked by the weight of events, the experience of the Holocaust made him a premature adult compared to his peers, because "they were 15-year-old children and we were 15-year-old adults. We lived mentally in completely different worlds" (Baláž, 2010, p. 55). In his experience there is an explicit parallel with the fate of The Lost Generation. There is only one difference: while the war made young students - soldiers (fighting in World War I.) people raw and superficial for the experience with killing; students - Jews who faced the Holocaust experienced their trauma from the horror committed on members of their own family. Their suffering stemmed from fear of deportations, constant concealment and fear of betraying their Jewish origins. For both, however, the war meant the end of their joyful childhood and adolescence (Adamická, 2019, p. 77).

These motifs also got into the memoirs of two Slovak Jews, the authors of the Auschwitz Protocol, Rudolf Vrba (Valter Rosenberg) and Jozef Lánik (Alfred Wetzler) who escaped from Auschwitz. In the book What Dante Did Not See, Jozef Lánik recalls his first contact with freedom with certain negative emotions or even fears about his own future. Among other things, they initially encountered distrust of their report, which bore witness to the atrocities against Jews committed in Auschwitz: "In the whole three months, he did not meet a person who would accept the rumors of mass murder in concentration camps without reservations, without a remark about propaganda" (Lánik, 1989, p. 254). At the same time, they were haunted by a certain exclusion from society - they could not be included in normal life, they were too distant from other people's lives. It could be said: they did not understand the world and the world did not understand them. "He's still a number, he can't (and maybe doesn't even know anymore) be laughing and having fun carefree. And what would he talk to them about? Maybe he would start talking. And they would not believe" (Lánik, 1989, p. 260).

Rudolf Vrba mentions the first moments after his escape from Auschwitz and his arrival in Slovakia, similarly to Jozef Lánik, with whom he "doubted whether we would be happy again or whether Auschwitz, the scene of so many murders, was immortal and will live in our minds until we will not die [...]In these dark moments, we were afraid that we might never be able to live a normal life again" (Vrba - Bestic, 2015, p. 323).

In a slightly different form, the motif of The Lost Generation also got into Peter Karvaš's prose The Old Man and Fate from the collection The Night in My City. In this case, it is not directly about capturing the nonsense or uselessness of one's own existence in the post-war period, but about the motif of losing childhood and adolescence under the influence of fear for one's life in the period of persecution of Jews. Marianka, the daughter of a Jewish watchmaker, was expelled from school because of her background, and by doing so, she distanced herself from her peers. At the same time, with the loss of her childhood, the watchmaker seemed to have lost his daughter, because "her adolescence with squeaky braids and the smell of student's books, everything was far in the past, in another world" (Karvaš, 1998, p. 81). Klára Jarunková also writes about the lost childhood in her novel The Black Solstice. The story of the novel is about an effort to save the childhood of the youngest daughter of mother Malatincová. Unlike Marianka's father from Karvaš's prose, mother Malatincová does not take this fact so pessimistically - Zuzka is reborn from a sick child into a strong adult woman, "into a wise and bold mother's support" (Jarunková, 1998, p. 118). It should be added, that while Marianka becomes a premature adult under the influence of the persecution of Jews, Zuzka experiences war from the opposite side - her family is non-Jewish, but during the war they hide Jews in their flat in Banská Bystrica, in the town which was the center of Slovak National Uprising. The panic of Zuzka does not stem from fear of deportations, but from betrayal and subsequent persecution.

The theme of the lost childhood was also marginally included in Rudolf Jašík's novel St. Elizabeth's Square. The young Jew Eva loses her adolescence after she starts living with Igor. She doesn't feel naturally in the role of Igor's partner, with whom she shares a bed. Their young, innocent love was hastened, though Eva was not identified with it. The deportation of the Jews made them prematurely adults: "They forgot about the tower, they both forgot about it: 'We forgot about you, a sign of our love, motherguardian! And is it because we stopped being children? Soon and so suddenly. Why did we stop being children? Every night when I make the bed, my hands shake and it seems to me that I am doing something forbidden' " (Jašík, 1962, p. 215). In this novel, as in previous works, there is expressed a rapid shift in life from childhood to adulthood over a few days under the influence of adverse circumstances. The only difference is in the range of characters affected by this aspect. Jašík goes further the motif of premature adulthood does not only concern the Jew Eva, but also the non-Jewish character Igor, who thus seems to connect his fate with the fate of the Jews. 


\section{Conclusion}

Works of Slovak literature depicting the issue of the Jewish minority and the Holocaust during World War II. are a valuable testimony reflecting the conditions of society in relation to Jews. There is also evidence of existential problems experienced by Jews during internment in concentration camps or escape attempts, as well as in the post-war period as a result of horrors they had experienced. And these difficulties created an imaginary obstacle to their efforts to reintegrate into society. There is no doubt that existential motifs are dominant in the memoir literature of the surviving Jews, who wanted to testify through literature and thus preserve the Holocaust for future generations. However, they got into the fiction of authors of non-Jewish origin depicting the machinery of the mass murder of Jews. It could be said that in this respect there is a very strong parallel between the memoirs of Jewish authors and the fiction of non-Jewish authors. This aspect is more evident in those works that were written on the basis of the personal testimonies of the surviving Jews and thus take on the character of memoirs.

However, it is not possible to generalize and state on the basis of a comparison of selected works that the same or at least similar existential motives occur in all works of Slovak literature depicting the Holocaust and the theme of Judaism. An example is Ladislav Grosman's short story The Bride (1968, Nevesta), which, although thematically focuses on the persecution of Jews during World War II., does not portray the existential motives we have described to such an extent. The plot of the novel is carried in a light-hearted spirit with a certain amount of humor. Only at the end of the story Lízinka, hidden under straw in a barn, asks herself existential questions: "What did she do, what is her fault? Is this a shelter for a person who has ceased to be human for the world and for reasons that cannot be understood?" (Grosman, 2017, p. 53). The author summed up in one sentence the degradation of the human dignity of the Jews during racial persecution, but on this basis it is not possible to claim about dominant existential motives as an important component of narration.

\section{Literature:}

Literary Sources

1. Baláž, Anton: Portréty prežitia. Bratislava: Milanium, 2014, 259 p. 978-80-89178-57-5.

2. Baláž, Anton: Tábor padlých žien. Bratislava: Slovenský spisovatel', 1993, 254 p. ISBN 80-220-0484-7.

3. Baláž, Anton: Transporty nádeje. Bratislava: Marenčin PT, 2010, 229 p. ISBN 978-80-8114-034-1.

4. Coddington, Andrea: Židovka. Bratislava: Ikar, 2010, 239 p. ISBN 978-80-551-2349-3.

5. Grosman, Ladislav: Obchod na Korze. Praha: Volvox Globator, 1992, 109 p. ISBN 80-85769-17-4.

6. Grosman, Ladislav: Nevesta. Bratislava: SNM - Múzeum židovskej kultúry, 2017, 60 p. ISBN 978-80-8060-409-7.

7. Havranová, Ivana: Odvlečení. Bratislava: Marenčin PT, 2017, 140 p. ISBN 978-80-8114-852-1.

8. Jarunková, Klára: Čierny slnovrat. In Božia ulička. Antológia slovenskej literatúry o holokauste. Bratislava: Vydavatel'stvo spolku slovenských spisovatel'ov, 1998, pp. 99-120. ISBN 9788088735816.

9. Jašík, Rudolf: Námestie svätej Alžbety. Bratislava: Tatran, 1976, 337 p.

10. Karvaš, Peter: Starý pán a osud. In Božia ulička. Antológia slovenskej literatúry o holokauste. Bratislava: Vydavatel'stvo spolku slovenských spisovatel'ov, 1998, pp. 65-82. ISBN 9788088735816.

11. Lahola, Leopold: Posledná vec. Bratislava: Slovenský spisovatel', 1968, 311 p.

12. Lánik, Jozef: Čo Dante nevidel. Bratislava: Obzor, 1989, 264 p.

13. Mňačko, Ladislav: Smrt' sa volá Engelchen. Bratislava: Európa, 2016, 221 p. ISBN 978-80-89666-29-4.

14. Remarque, Erich Maria: Na západe nič nové. Bratislava: Smena, 1977, $174 \mathrm{p}$.

15. Richter, Milan: Vo mne zbúraný chrám. Dunajská Lužná: Milanium, 2002, 71 p. ISBN 8096870459.
16. Schwalbová, Manca: Vyhasnuté oči. Bratislava: Marenčin PT, 2011, 154 p. ISBN 978-80-8114-104-1.

17. Volanská, Hela: Ako na cudzej svadbe. Bratislava: Marenčin PT, 2009, 245 p. ISBN 978-80-89218-93-6.

18. Vrba, Rudolf - Bestic, Alan: Nemôžem odpustit'. Utiekol som z Osvienčimu. Bratislava: Citadella, 2015, 504 p. ISBN 9788089628834

19. Wandall-Holmová, Iboja: Osvienčim-Brezinky. In Božia ulička. Antológia slovenskej literatúry o holokauste. Bratislava: Vydavatel'stvo spolku slovenských spisovatel'ov, 1998, pp. 224230. ISBN 9788088735816.

\section{Scientific literature}

1. Adamická, Monika: Slovenské židovstvo v tvorbe Antona Baláža. Nitra: Univerzita Konštantína Filozofa, 2019, 116 p. ISBN 978-80-558-1427-8.

2. Domorák, Daniel: Východiská poetiky rekonfigurácie v existenciálnom diskurze slovenskej literatúry po roku 1945. In Slovenská literatúra, vol. 64, nr. 3, 2017, pp. 192 - 200. ISSN 0037-6973.

3. Gallik, Ján: Formovanie stereotypného pohl'adu na Židov v slovenskej tlači. In Imagológia ako výskum obrazov kultúry (K reflexii etnických stereotypov krajín V4). Nitra: Univerzita Konštantína Filozofa v Nitre, Fakulta stredoeurópskych štúdií, 2018, pp. 73 - 86. ISBN 978-80-558-1294-6.

4. Gallik, Ján - Vargová, Zuzana: Durychova novela „Boží duha“ vo filmovom spracovaní. In: World Literature Studies, vol. 2, nr. 3, 2019, pp. 28 - 41. ISSN 1337-9275.

5. Jaspers, Karl: Otázka viny. Příspěvek k německé otázce. Praha: Academia, 2006, 143 p. ISBN 80-200-1455-1.

6. Šuša, Ivan: K špecifikám memoárov $\mathrm{z}$ prostredia koncentračných táborov. In Slavica Litteraria. Brno: FF MU, vol. 18, nr. 2, 2015a, pp. 129 - 139. ISSN 1212-1509.

7. Šuša, Ivan: Život za ostnatými drôtmi (K slovenskej memoárovej literatúre z obdobia holokaustu). In Nový život, vol. 67, nr. 1 - 2, 2015 b, pp. 40 - 45. ISSN 0351-3610.

8. Vargová, Zuzana: Židovský fenomén $v$ stredoeurópskych súvislostiach. Nitra: UKF, 2011, 108 p. ISBN 978-80-8094-964-8.

Internet

1. Heidegger, Martin: Bytí a čas. Praha: Oikoymenh, 2002, 487 p. Online: https://epdf.pub/queue/byti-a-as.html.

2. Spravodlivý medzi národmi. Online: https://www.pribehy spravodlivych.sk/spravodlivi-medzi-narodmi/.

\section{Primary Paper Section: A}

Secondary Paper Section: AA, AB, AJ 